anales de psicología / annals of psychology

2021, vol. $37, \mathrm{n}^{\circ} 1$ (january), 142-148

https://doi.org/10.6018/analesps.414411
(C) Copyright 2021: Editum. Servicio de Publicaciones de la Universidad de Murcia. Murcia (Spain) ISSN print edition: 0212-9728. ISSN online edition (http://revistas.um.es/analesps): 1695-2294

Online edition License Creative Commons 4.0: BY-SA

\title{
Character strengths as protective factors against engagement in sexting in adolescence
}

\author{
Paula Yépez-Tito ${ }^{1,}$, Marta Ferragut ${ }^{2}$, and María J. Blanca ${ }^{2}$ \\ 1 Universidad de Las Américas. Quito (Ecuador). \\ 2 University of Malaga. Málaga (Spain).
}

\begin{abstract}
Título: Fortalezas psicológicas como factores protectores frente a la participación de adolescentes en comportamientos de sexting.

Resumen: El sexting es una nueva forma de interacción sexual en adolescentes que ha sido asociada tanto a problemas psicológicos como comportamientos de riesgo sexual. Aunque varios estudios han examinado la relación entre sexting y rasgos de personalidad, su posible asociación con las fortalezas del carácter no ha sido aún explorada. El objetivo de este estudio fue analizar cuáles fortalezas de carácter podrían funcionar como factores protectores contra la participación en el sexting, controlando otras variables que puedan influenciar esta relación. Los adolescentes cumplimentaron cuestionarios sobre recursos tecnológicos, sexting activo y fortalezas de carácter. Los resultados de la regresión lineal mostraron que el sexting activo estuvo positivamente relacionado con las fortalezas de curiosidad y humor y negativamente relacionado con justicia y autenticidad. Estos resultados sugieren que los programas escolares o familiares que tengan como objetivo la prevención del sexting deberían incluir actividades específicas que fomenten el uso positivo de la curiosidad y el humor y que busquen promover la honestidad, el respeto, la justicia y la responsabilidad en el uso de la tecnología para las relaciones interpersonales.

Palabras clave: Sexting activo. Fortalezas de carácter. Virtudes. Compor tamientos de riesgo. Adolescencia.
\end{abstract}

\section{Introduction}

Sexting, which refers to the exchange of sexual messages or images by technological means (Klettke et al., 2014), is an emergent phenomenon reflecting a new kind of intimate communication between adolescents. The behavior is classified as either active or passive. Passive sexting includes receiving, asking for, or being asked for sexually explicit material, whereas active sexting refers to creating, showing, posting, sending, or forwarding of such material (Barrense-Dias et al., 2017; Temple \& Choi, 2014).

The most common profile of a person who engages in active sexting is a late-adolescent male with access to more technological resources and who is in a romantic relationship, although sexting behaviors have also been observed among early adolescents (Baumgartner et al., 2014; Lippman \& Campbell, 2014; Morelli et al., 2016a, 2016b; Rice et al., 2014; Strassberg et al., 2017; Yépez-Tito et al., 2020). Research suggests that sexting is a way of expressing sexuality with peers (Barrense-Dias et al., 2017; Kopecký, 2012, 2015; Lippman \& Campbell, 2014; Ševčíková, 2016; Van Ouytsel et al., 2016), which is consistent with the fact that the principal motivations for sexting, aside from joking, are wanting to

* Correspondence address [Dirección para correspondencia]:

Paula Yépez-Tito. Universidad de Las Américas - Ecuador. Campus Udlapark - Redondel el Ciclista, Vía Nayón. CP: 170401. Quito (Ecuador). E-mail: paulayepez@gmail.com

(Article received: 12-02-2020; revised: 23-06-2020; accepted: 15-07-2020)
Abstract: Sexting is a new kind of sexual interaction among adolescents that has been linked to both psychological problems and sexual risk behaviors. Although studies have examined the relationship between sexting and personality traits, its possible association with character strengths remains unexplored. The aim of this study was to analyze which character strengths may function as protective factors against engagement in sexting, controlling for other variables that might influence this relationship. Adolescents completed questionnaires about technological resources, active sexting, and character strengths. The results from hierarchical regression showed that active sexting was positively related to the strengths of curiosity and humor and negatively related to fairness and authenticity. These findings suggest that school- or family-based programs aimed at preventing sexting should include specific activities that encourage a positive use of curiosity and humor and which seek to promote honesty, respect, fairness, and responsibility in the use of technology for interpersonal relationships.

Keywords: Active sexting. Character strengths. Virtues. Risk behaviors. Adolescence.

have sex and dating (Korenis \& Billick, 2014; Lippman \& Campbell, 2014; Yépez-Tito et al., 2018).

Sexting may have negative consequences for adolescents. Empirical evidence suggest that the behavior is associated not only with emotional problems such as distress, anxiety, and depression (Dake et al., 2012; Drouin \& Landgraff, 2012; Mori et al., 2019; Reid \& Weigle, 2014; Ringrose et al., 2012), but also with harassment, blackmailing, illegal distribution of images, grooming, cyberbullying, substance abuse, and sexual risk behaviors (Cruz \& Soriano, 2014; GámezGuadix et al., 2017; Livingstone \& Görzig, 2014; Michaud \& Free, 2017; Mori et al., 2019; Reid \& Weigle, 2014; Temple et al., 2014; Ybarra \& Mitchell, 2014). Identifying variables which might predict sexting behavior is therefore important, as a deeper understanding of the phenomenon is necessary in order to develop intervention programs aimed at preventing it and promoting the appropriate use of communication technologies. In this context, some researchers have examined the relationship between sexting and personality traits. These studies, conducted mostly with adults or young adults, have linked greater engagement in sexting to high levels of neuroticism, extraversion (Delevi \& Weisskirch, 2013), histrionic traits (Ferguson, 2011), impulsivity (Charnigo et al., 2013; Dir et al., 2013; Temple \& Choi, 2014), and sensation seeking (Dir et al., 2013), as well as to low levels of agreeableness (Delevi \& Weisskirch, 2013).

In adolescents, Van Ouytsel, Van Gool, Ponnet, and Walrave (2014) found that those who scored higher on sensation seeking and experiential thinking were more likely to engage in sexting, whereas those who scored higher on ra- 
tional thinking tended to send less suggestive messages. Other authors have found a positive association between sexting behavior and impulsivity (Gregg et al., 2018; Temple et al., 2014). Recent research has also shown that adolescents who engage in sexting behaviors score lower on agreeableness and conscientiousness and higher on extraversion, suggesting that those who are emotionally vulnerable practice sexting in order to be accepted into peer groups (Alonso \& Romero, 2019).

The majority of the abovementioned studies have been based on the five-factor model of personality. However, the relationship between sexting and personality traits can be extended from the perspective of positive psychology by considering the model of personality proposed by Peterson and Seligman (2004). These authors introduced the concepts of character strengths, considered to be personality characteristics with a moral component that are visible in the emotions, behaviors, and thoughts of individuals (Park \& Peterson, 2008). Character strengths are measurable and relatively stable, although flexible enough to allow further development (Peterson \& Seligman, 2004). In their model, Peterson and Seligman (2004) identified 24 character strengths, classified into six virtues (Wisdom and Knowledge, Courage, Humanity, Justice, Temperance, and Transcendence). The results of several studies suggest that character strengths are a key factor in relation to life satisfaction and wellbeing (Blanca et al., 2018; Giménez, 2010; Ovejero et al., 2016; Park, 2004; Proctor et al., 2011; Reyes \& Ferragut, 2016; Toner et al., 2012; Weber \& Ruch, 2012). Importantly, strengths may also act as protective factors against risk behaviors and difficulties in adolescence. Some studies, for example, have found that adolescents with numerous character strengths have a reduced risk of developing psychiatric disorders, violent behaviors, and interpersonal difficulties in early adulthood (Bromley et al., 2006). Similarly, adolescents who have higher levels of strengths such as honesty, prudence, and love experience fewer behavioral problems, fewer symptoms of depression, and lower levels of anxiety (Gillham et al., 2011; Park \& Peterson, 2006). In addition, higher scores on leadership among girls have been associated with greater confidence in negotiating safe sex, while higher scores on love of learning predict abstinence from drug use in both girls and boys (Ma et al., 2008). Also Ferragut, Blanca and Ortiz-Tallo (2013) found that the psychological virtues were related to the sexist attitudes in preadolescents, concluding that these are important variables to be taked into account in education and psychological preventive programs.

Given that character strengths may function as protective factors against certain psychological problems and risky sexual behaviors in adolescence, it is plausible that they might play a similar role in relation to sexting during the same life stage, one in which sexuality becomes a way of interacting with peers. Knowing what strengths might be protective factors, and also whether certain strengths might actually be related to a greater likelihood of engaging in this behavior could serve as a platform for prevention and intervention programs aimed at tackling the problems associated with technology misuse. These programs should be implemented from early adolescence, which is the stage when communication technology begins to be used independently from parents (Yépez-Tito et al., 2018).

To our knowledge, however, no previous studies have analyzed the relationship between active sexting and character strengths in adolescents. The aim of the present study was therefore to analyze which character strengths may function as protective factors against sexting and which of them are related to greater engagement in active sexting during adolescence, controlling for other variables that might influence this relationship, specifically, gender, age, the amount of available technological resources, and being in a romantic relationship.

\section{Method}

\section{Participants}

Participants were 664 adolescents (288 girls and 376 boys) aged between 12 and 18 years $(M=14.6, S D=1.74)$ and recruited from five schools in the metropolitan area of Quito (Ecuador). The schools were selected by convenience and were located in areas of different socioeconomic status. The inclusion criteria for participants were: (1) age between 12 and 18 years, (2) Spanish as their mother tongue, (3) not having an officially recognized psychological problem, and (4) informed consent for participation signed by their parents/legal guardians. Participating classes within each school were selected randomly and covered the full range of secondary and baccalaureate education (12-13 years old: $31.5 \%$; 14-16 years old: $50.2 \% ; 17-18$ years old: $18.4 \%$ ). In terms of romantic relationships, $54.5 \%$ of the adolescents stated that they did not currently have a partner, while the remaining $45.5 \%$ said they did.

\section{Instruments}

Technological resources questionnaire. This questionnaire had five items, each with two response options (yes $=1$, no $=0$ ): Do you have a computer at home? Do you have an internet connection at home? Do you have a mobile phone? Can you access the internet with your mobile phone? Do you have a tablet? Higher scores indicate that the respondent has more technological resources.

Active sexting questionnaire. Sexting behavior was measured using the six items referring to active sexting on the Sexting Behaviors Scale (SBS), an instrument developed by ChacónLópez, Romero, Aragón, and Caurcel (2016) and validated in the Ecuadorian context by Yépez-Tito et al. (2018). The items are rated on a five-point Likert scale from 0 to 4 (never/rarely; sometimes/several times a month; often/several times a week; frequently/daily). Higher scores indicate greater engagement in active sexting using a cell phone or social 
networking sites. Cronbach's alpha for the present sample was .86 .

$V$ alues in Action Inventory of Strengths for Youth (VLA-Youth). We used the Spanish version (Vázquez \& Hervás, 2007) of the VIA-Youth (Park \& Peterson, 2006), which has been shown to have adequate psychometric properties (Giménez, 2010). The inventory contains 198 items that are responded to using a five-point Likert scale $(1=$ not at all like me; $5=$ very much like me). The VIA-Youth assesses 24 character strengths that are classified into six values: Wisdom and Knowledge (creativity, curiosity, love of learning, openmindedness, and perspective); Courage (bravery, persistence, authenticity, and zest); Humanity (love, kindness, and social intelligence); Justice (teamwork, fairness, and leadership); Temperance (forgiveness, modesty, prudence, and selfregulation); and Transcendence (appreciation of beauty and excellence, gratitude, hope, humor, and religiousness). Cronbach's alpha in the present sample ranged from .60 to .79. Higher scores indicate a stronger endorsement of that strength.

\section{Procedure}

The study was conducted in accordance with the Declaration of Helsinki. It was approved by the National Directorate of Research of the Ministry of Education in Ecuador and supervised by the principal of each participating school. Informed consent was signed by parents/legal guardians, as well as by the adolescents themselves. Adolescents completed the abovementioned questionnaires in a single session during their normal school timetable under the supervision of a teacher and a psychologist. Their participation was voluntary and anonymous. After data collection, researchers informed each of the participating schools about the results obtained, providing information about sexting behaviors and their possible implications in adolescents.

\section{Data Analysis}

In order to analyze the relationship between active sexting and character strengths we conducted a hierarchical regression analysis with active sexting as the dependent variable. Two blocks of independent variables were entered. The first included the sociodemographic variables as control variables: gender, age, amount of available technological resources, and being in a romantic relationship. In the second block, we entered the 24 character strengths.

\section{Results}

Table 1 shows descriptive statistics for the predictors entered in the regression analysis, the results of which are shown in Table 2.

The model obtained when sociodemographic variables were introduced in the first stage of the hierarchical regression explained $15 \%$ of the variance in active sexting. When the 24 strengths were included, the regression model explained $23 \%$ of the variance. The results of the second stage of the hierarchical regression show that scores on active sexting are higher in boys and are positively associated with age and with having more technological resources. In addition, they are positively related to curiosity and humor, and negatively related to fairness and authenticity.

Table 1. Mean and standard deviation $(S D)$ for scores on active sexting, availability of technological resources, and the 24 character strengths $(N=$ 664).

\begin{tabular}{lcc}
\hline Variables & Mean & $S D$ \\
\hline Active sexting & 2.31 & 3.50 \\
Technological resources & 4.66 & 1.26 \\
Creativity & 3.73 & 0.69 \\
Curiosity & 3.70 & 0.64 \\
Love of learning & 3.84 & 0.68 \\
Open-mindedness & 3.64 & 0.59 \\
Perspective & 3.44 & 0.62 \\
Bravery & 3.66 & 0.67 \\
Persistence & 3.61 & 0.66 \\
Authenticity & 3.51 & 0.66 \\
Zest & 3.59 & 0.72 \\
Love & 3.69 & 0.68 \\
Kindness & 3.74 & 0.62 \\
Social intelligence & 3.50 & 0.55 \\
Teamwork & 3.90 & 0.63 \\
Fairness & 3.62 & 0.57 \\
Leadership & 3.22 & 0.72 \\
Forgiveness & 3.37 & 0.87 \\
Modesty & 3.48 & 0.59 \\
Prudence & 3.27 & 0.64 \\
Self-regulation & 3.38 & 0.65 \\
Appreciation of beauty & 3.82 & 0.66 \\
Gratitude & 4.13 & 0.59 \\
Hope & 3.82 & 0.72 \\
Humor & 3.64 & 0.73 \\
Religiousness & 3.91 & \\
\hline
\end{tabular}

Table 2. Results from hierarchical regression analysis with active sexting as the dependent variable: Standardized regression coefficients, $F$ statistic, $R$ squared, and increment in $\mathrm{R}$-squared $(N=664)$.

\begin{tabular}{|c|c|c|c|c|}
\hline Variables & Stage 1 & Stage2 & $F$ & $R^{2} \Delta R^{2}$ \\
\hline Sociodemographic variables & & & $27.93^{* *}$ & $.15 .15^{* *}$ \\
\hline Gender & $.24 * *$ & $.19^{* *}$ & & \\
\hline Age & $.19^{* *}$ & $.20^{* *}$ & & \\
\hline Technological resources & $.14^{* *}$ & $.13^{* *}$ & & \\
\hline Having a partner & $.11 * *$ & .06 & & \\
\hline Strengths & & & $6.86 * *$ & $.23 .08 * *$ \\
\hline Creativity & & -.06 & & \\
\hline Curiosity & & $.16^{* *}$ & & \\
\hline Love of learning & & -.06 & & \\
\hline Open-mindedness & & -.07 & & \\
\hline Perspective & & .07 & & \\
\hline Bravery & & -.01 & & \\
\hline Persistence & & -.01 & & \\
\hline Authenticity & & $-.11 *$ & & \\
\hline Zest & & -.03 & & \\
\hline Love & & -.04 & & \\
\hline Kindness & & -.06 & & \\
\hline Social intelligence & & -.10 & & \\
\hline
\end{tabular}




\begin{tabular}{|c|c|c|c|c|}
\hline Variables & Stage 1 & Stage2 & $F$ & $\begin{array}{ll}R^{2} \quad \Delta R^{2} \\
\end{array}$ \\
\hline teamwork & & .04 & & \\
\hline Fairness & & $-.12 *$ & & \\
\hline Leadership & & .03 & & \\
\hline Forgiveness & & .01 & & \\
\hline Modesty & & .01 & & \\
\hline Prudence & & -.05 & & \\
\hline Self-regulation & & -.01 & & \\
\hline Appreciation of beauty & & .08 & & \\
\hline Gratitude & & .03 & & \\
\hline Hope & & 11 & & \\
\hline Humor & & $.10 *$ & & \\
\hline Religiousness & & -.01 & & \\
\hline
\end{tabular}

\section{Discussion}

The aim of this study was to analyze which character strengths may function as protective factors against sexting and which of them are related to greater engagement in active sexting during adolescence, controlling for other variables that might influence this relationship (i.e., gender, age, amount of available technological resources, and being in a romantic relationship). The results of the last stage of the hierarchical regression showed that gender, age, and the amount of available technological resources are all related to the practice of active sexting. Consistent with previous studies on the prevalence of sexting, we found that active sexting is more prevalent among boys (Baumgartner et al. 2014; Lippman \& Campbell, 2014; Morelli et al. 2016a; Rice et al., 2014; Strassberg et al., 2013, 2017; Yépez-Tito et al., 2018) and that it is positively related to age (Baumgartner et al., 2014; Gámez-Guadix et al., 2017; Lippman \& Campbell, 2014; Morelli et al., 2016b; Rice et al., 2014; Ybarra \& Mitchell, 2014; Yépez-Tito et al., 2018). Adolescents with more technological resources are also more likely to engage in active sexting, probably because of their increased opportunities to interact with virtual media (Campbell \& Park, 2014; Yépez-Tito et al., 2020).

In relation to character strengths, the regression analysis identified four that were significant predictors of active sexting: curiosity, humor, fairness, and authenticity. Active sexting was positively associated with both curiosity and humor. Curiosity is related to cognitive processes and the use of knowledge, and it is defined as the interest in knowledge and in something new (Peterson \& Seligman, 2004). People with the attribute of curiosity are more fluid and open to new experiences and ideas (Kashdan et al., 2004; Park \& Peterson, 2006). One manifestation of curiosity is novelty-seeking and a propensity to seek out exciting experiences, which may have negative repercussions if it is associated with risk behaviors such as illegal substance use or risky sexual behaviors (Peterson \& Seligman, 2004). In this respect, studies have found that excessive curiosity is related to substance use, gambling, and morbid fascination (Zuckerman, 1994), and a positive relationship between curiosity and internet addiction and anxiety has also been reported (Choi et al., 2015). It is possible, therefore, that the desire to learn and to search for new experiences may lead adolescents to engage more in active sexting.

The strength of humor is defined as a preference for laughter and jokes and the ability to make others smile (Peterson \& Seligman, 2004). Sense of humor is strongly associated with social stereotypes (Giménez, 2010) and it is one of the strengths that predominate in adolescents (Ferragut et al., 2014b; Giménez, 2010, Park \& Peterson, 2006) and which can be a sign of peer status in a classroom (Wagner, 2019). Although humor has been related to positive outcomes such as better recovery from psychological disorders, physical illness, or trauma events (Peterson et al., 2006), it is also related to sarcasm and to ridiculing others (Peterson \& Seligman, 2004). Consequently, it needs to be accompanied by other strengths such as prudence and kindness if it is to be used appropriately and not be perceived as hurtful to a peer (Gillham et al., 2011). An improper use of humor might lead adolescents towards greater engagement in active sexting, which is consistent with the fact that joking is considered one of the main motivations for sexting among adolescents (Korenis \& Billick, 2014; Lippman \& Campbell, 2014; YépezTito et al., 2018).

Our analysis also showed that fairness and authenticity were negatively related to active sexting. Fairness refers to the process by which people determine what is morally right or wrong (Peterson \& Seligman, 2004), to the ability to treat everybody the same according to the same criteria of justice (Park et al., 2004). Fairness is a strength that is highly valued by adolescents in friendships and it is linked to trustworthiness (Wagner, 2019), a characteristic on which students considered "popular" score high (Park \& Peterson, 2006). The strength of authenticity is defined as the ability to live in a genuine way, which implies taking responsibility for one's own actions and feelings (Peterson \& Seligman, 2004). Authenticity is more common among adults than youth because it requires a certain degree of personality maturation (Park \& Peterson, 2006). Related to this finding, some authors have reported that adolescents who score high on rational thinking are less likely to engage in sexting (Van Ouytsel et al., 2014). Consistent with this, our results suggest that adolescents who are more responsible, reflexive, and fair also engage less in sexting.

Overall, the results of this study show that active sexting is more common among boys, older adolescents, those with more technological resources, and those who score higher on curiosity and humor or lower on fairness and authenticity. The first point to consider here is that curiosity and humor, although usually regarded as strengths, may be associated with negative or harmful behaviors in adolescence if they are not used appropriately (Choi et al., 2015; Gillham, 2011; Peterson \& Seligman, 2004; Zuckerman, 1994). By contrast, the character strengths of fairness and authenticity appear to protect against engagement in sexting, suggesting that adolescents who seek to be true to themselves and to treat oth- 
ers fairly will be more likely to behave responsibly in their relationships with peers.

Given that sexting may have negative consequences for adolescents, our results have certain clinical and educational implications. Since adolescence is a period of life characterized by risk taking, impulsivity, sexual curiosity, and selfexploration (Korenis \& Billick, 2014), helping young people to develop, enhance, and use certain character strengths may help them, in their transition to adulthood, to distinguish more clearly between right and wrong and to accept responsibility for their own actions. In this context, Ferragut, Blanca, and Ortiz-Tallo (2014a) found that the skills associated with relationships to others and the sense of fairness and justice improve over time, leading them to argue that efforts should be directed at developing and reinforcing these strengths from the beginning of adolescence. The present results suggest that school- or family-based programs aimed at preventing sexting and educating adolescents about the associated risks should include specific activities that encourage a positive use of curiosity and humor and which seek to promote honesty, respect, fairness, and responsibility in the use of technology for interpersonal relationships.

Our study does have certain limitations. First, the participants were all from the city of Quito, and hence the findings may not be generalizable to other regions of Ecuador or other countries. Second, all the measures used were selfreports, with the inherent possibility of bias that this implies.

\section{References}

Alonso, C., \& Romero, E. (2019). Sexting behaviours in adolescents. Personality predictors and psychosocial outcomes in a one-year follow-up. Anales de Psicología, 35, 214-224. https://doi.org/10.6018/analesps.35.2.339831

Barrense-Dias, Y., Berchotold, A., Surís, J., \& Akre, C. (2017). Sexting and the definition Issue. Journal of Adolescent Health, 61, 544-554. https://doi.org/10.1016/j.jadohealth.2017.05.009

Baumgartner, S., Sumter, S., Peter, J., Valkenburg, P., \& Livingstone, S. (2014). Does country context matter? Investigating the predictors of teen sexting across Europe. Computers in Human Behavior, 34, 157-164. https://doi.org/10.1016/j.chb.2014.01.041

Blanca, M. J., Ferragut, M., Ortiz-Tallo, M., \& Bendayan, R. (2018). Life Satisfaction and character strengths in Spanish early adolescents. Journal of Happiness Studies, 19, 1247-1260. https://doi.org/10.1007/s10902-0179865-y

Bromley, E., Johnson, J. G., \& Cohen, P. (2006). Personality strengths in adolescence and decreased risk of developing mental health problems in early adulthood. Comprehensive Psychiatry, 47, 315-324. https://doi.org/10.1016/j.comppsych.2005.11.003

Campbell, S., \& Park, Y. (2014). Predictors of mobile sexting among teens: Toward a new explanatory framework. Mobile Media \& Communication, 2, 20-39. https://doi.org/10.1177/2050157913502645

Chacón-López, H., Romero, J., Aragón, Y., \& Caurcel, M. (2016). Construcción y validación de la Escala de Conductas sobre sexting (ECS) [Construcción y validación de la Escala de Conductas sobre sexting (ECS)]. Revista Española de Orientación y Psicopedagogía, 27, 99-115. https://doi.org/10.5944/reop.vol.27.num.2.2016.17116

Charnigo, R., Noar, S., Garnett, C., Crosby, R., Palmgreen, P., \& Zimmerman, R. (2013). Sensation Seeking and Impulsivity: Combined Associations with Risky Sexual Behavior in a Large Sample of Young Adults. Journal of Sex Research, 50, 480-488. https://doi.org/10.1080/00224499.2011.652264

\section{Conclusions}

The present study, conducted within the positive psychology framework, adds to knowledge about sexting and its relationship with personality traits. The results show that those adolescents who score higher on curiosity and humor, and lower on fairness and authenticity are more likely to engage in sexting. These findings may serve as a platform for the design of prevention and educational programs aimed at promoting the appropriate use of communication technologies. More specifically, our results suggest that such programs should include specific activities that encourage a positive use of curiosity and humor and which seek to promote honesty, respect, fairness, and responsibility in interpersonal relationships.

Conflict of Interest.- The authors of this article declare no conflict of interest.

Funding.- This research did not receive any specific grant from funding agencies in the public, commercial, or not-for-profit sectors.

Acknowledgments.- This research has been possible thanks to the collaboration of the adolescents and their parents, the educational institutions, and the psychologists who participated in the research process.

Choi, S. W., Kim, D. J., Choi, J. S., Ahn, H., Choi, E. J., Song, W. Y., Kim, S., \& Youn, H. (2015). Comparison of risk and protective factors associated with smartphone addiction and Internet addiction. Journal of Behavioral Addictions, 4, 308-314. https://doi.org/10.1556/2006.4.2015.043

Cruz, L. \& Soriano, E. (2014). Psychological aspects, attitudes and behaviour related to the practice of sexting: A systematic review of the existent literature. Procedia - Social and Behavioral Sciences, 132, 114-120. https://doi.org/10.1016/j.sbspro.2014.04.286

Dake, J., Price, J., Maziarz, L., \& Ward, B. (2012). Prevalence and correlates of sexting behavior in adolescents. American Journal of Sexuality Education, 7, 1-15. https://doi.org/10.1080/15546128.2012.650959

Delevi, R. \& Weisskirch, R. (2013). Personality factors as predictors of sexting. Computers in Human Behaviors, 29, 2589-2594. https://doi.org/10.1016/j.chb.2013.06.003

Dir, A., Cyders, M., \& Coskunpinar, A. (2013). From the bar to the bed via mobile phone: A first test of the role of problematic alcohol use, sexting, and impulsivity-related traits in sexual hook-ups. Computers in $\mathrm{Hu}$ man Behavior, 29, 1664-1670. https://doi.org/10.1016/j.chb.2013.01.039

Drouin, M. \& Landgraff, C. (2012). Texting, sexting and attachment in college student's romantic relationships. Computers in Human Behavior, 28 444-449. https://doi.org/10.1016/j.chb.2011.10.015

Ferguson, C. (2011). Sexting Behaviors Among Young Hispanic Women: Incidence and Association with Other High-risk Sexual Behaviors. Psychiatric Quarterly, 82, 239-243. https://doi.org/10.1007/s11126-0109165-8

Ferragut, M., Blanca, M. J., \& Ortiz-Tallo, M. (2013). Psychological values as protective factors against sexist attitudes in preadolescents. Psicothe ma, 25, 38-42. https://doi.org/10.7334/psicothema2012.85

Ferragut, M., Blanca, M. J., \& Ortiz-Tallo, M. (2014a). Psychological virtues during adolescence: A longitudinal study of gender differences. Europe- 
an Journal of Developmental Psychology, 11, 521-531. https://doi.org/10.1080/17405629.2013.876403

Ferragut, M., Blanca, M. J., \& Ortiz-Tallo, M. (2014b). Analysis of adolescent profiles by gender: strengths, attitudes toward violence and sexism. $\begin{array}{lllll}\text { Spanish Journal of Psychology, } & 17, & 1-10 .\end{array}$ https://doi.org/10.1017/sjp.2014.60

Gámez-Guadix, M. P., De Santisteban, P., \& Resett, S. (2017). Sexting among Spanish Adolescents: Prevalence and Personality Profiles. Psicothema 29, 29-34. https://doi.org/10.1080/17439760.2010.536773

Gillham, J., Adams-Deutsch, Z., Werner, J., Reivich, K., Coulter-Heindl, V., Linkins, M., Winder, B., Peterson, C., Park, N., Abenavoli, R., Contero, A., \& Seligman, M. (2011). Character strengths predict subjective wellbeing during adolescence. The Journal of Positive Psychology, 6, 31-44. http://dx.doi.org/10.1080/17439760.2010.536773

Giménez M. (2010). La medida de las fortalezas psicológicas en adolescentes (VIAYoutb): Relación con clima familiar, psicopatología y bienestar psicológico [Measurement of psychological strengths in adolescents (VIA-Youth): Relationship to family atmosphere, psychopathology and psychological well-being]. Doctoral dissertation. Madrid: Universidad Complutense.

Gregg, D., Somers, C.L., Pernice, F., Hillman, S.B., \& Kernsmith, P.C. (2018). Sexting rates and predictors from an urban midwest high school. Journal of School Health, 88, 423-433. https:// doi.org./10.1111/josh.12628

Kashdan, T., Rose, P., \& Finchman, F. (2004). Curiosity and exploration: Facilitating positive subjective experiences and personal growth opportunities. Journal of Personality Assessment, 82, 291-305. https://doi.org/10.1207/s15327752jpa8203_05

Klettke, B., Hallford, D., \& Mellor, D. (2014). Sexting prevalence and correlates: A systematic literature review. Clinical Psychology Review, 34, 44-53. https://doi.org/10.1016/j.cpr.2013.10.007

Kopecký, K. (2012). Sexting among Czech preadolescents and adolescents. The New Educational Review, 28, 39-48.

Kopecký, K. (2015). Sexting among Slovak pubescents and adolescent Children. Procedia - Social and Behavioral Sciences, 203, 244-250. https://doi.org/10.1016/j.sbspro.2015.08.289

Korenis, P. \& Billick, S. B. (2014). Forensic Implications: Adolescent Sexting and Cyberbullying. Psycbiatric Quarterly 85, 97-101. https://doi.org/10.1007/s11126-013-9277-z

Lippman, J.R. \& Campbell, S.W. (2014). Damned if you do, damned if you don't...if you are a girl: Relational and Normative Contexts of Adolescent Sexting in the United States. Journal of Children and Media, 8, 71-386. https://doi.org/10.1080/17482798.2014.923009

Livingstone, S. \& Görzig, A. (2014). When adolescents receive sexual messages on the internet: Explaining experiences of risk and harm. Computers in Human Behavior, 33, 8-15. https://doi.org/10.1016/j.chb.2013.12.021

Ma, M., Kibler, J. L., Dollar, K. D., Sly, K., Samuels, D., Benford, M. W., Coleman, M., Lott, L. T., Patterson, K., \& Wiley, F. (2008). The relationship of character strengths to sexual behaviors and related risks among African American adolescents. International Journal of Behavioral Medicine, 15, 319-327. https://doi.org/10.1080/10705500802365573

Michaud, P. \& Free, C. (2017). Alice in wonderland: Adolescents and digital technologies. In A. Cherry, V. Baltag, \& M. Dillon (Eds.). International Handbook on Adolescent Health and Development (pp. 397-409). Cham: Springer. https://doi.org/10.1007/978-3-319-40743-2_20

Morelli, M., Bianchi, D., Baiocco, R. Pezzuti, L., \& Chirumbolo, A. (2016a). Sexting behaviors and cyber pornography addiction among adolescents: The moderating role of alcohol consumption. Sexuality Research and Social Policy, 14, 113-121. https://doi.org/10.1007/978-3-319-40743-2_20

Morelli, M., Bianchi, D., Baiocco, R., Pezzuti, L., \& Chirumbolo, A. (2016b). Sexting, psychological distress and dating violence among adolescents and young adults. Psicothema 28, 137-142. http://doi.org/10.7334/psicothema2015.193

Mori, C., Temple, J., Browne, D. \& Madigan, S. (2019). Association of sexting with sexual behaviors and mental health among adolescents. A systematic review and meta-analysis. JAMA Pediatrics, 173, 770-779. http://doi.org/10.1001/jamapediatrics.2019.1658

Ovejero, M.M., Cardenal, V., \& Ortiz-Tallo, M. (2016). Fortalezas Humanas y Bienestar Biopsicosocial: Revisión sistemática [Character strengths and biopsychosocial well-being: A systematic review]. Escritos de Psicolo- gia, $\quad 9, \quad 4-14$ https://doi.org/10.5231/psy.writ.2016.2311https://doi.org/10.5231/p sy.writ.2016.2311

Park, N. (2004). Character strengths and positive youth development. American Academy of Political and Social Science, 591, 40- 54. https://doi.org/10.1177/0002716203260079

Park, N. \& Peterson, C. (2006). Moral competence and character strengths among adolescents: The development and validation of the Values in Action Inventory of Strengths for Youth. Journal of Adolescence, 29, 891909. https://doi.org/10.1016/j.adolescence.2006.04.011

Park, N. \& Peterson, C. (2008). Positive psychology and character strengths: Application to strengths-based school counseling. Professional School Counseling, 12, 85-92. https://doi.org/10.5330/PSC.n.2010-12.85

Park, N., Peterson, C., \& Seligman, M.E.P. (2004). Strengths of character and well-being. Journal of Social and Clinical Psychology, 23, 603-619. https://doi.org/10.1521/jscp.23.5.603.50748

Peterson, C., Park, N., \& Seligman, M.E.P. (2006). Greater strengths of character and recovery from illness. Journal of Positive Psychology, 1, 17-26. https://doi.org/10.1080/17439760500372739

Peterson, C. \& Seligman, M.E.P. (2004). Character strengths and virtues: A handbook and classification. Washington, DC: American Psychological Association and Oxford University Press.

Proctor, C., Tsukayama, E., Wood, A.M., Maltby, J., Eades, J.F., \& Linley, P.A. (2011). Strengths gym: The impact of a character strengths-based intervention on the life satisfaction and well-being of adolescents. The Journal of Positive Psychology, 6, 377-388. https://doi.org/10.1080/17439760.2011.594079

Reid, D. \& Weigle, P. (2014). Social media use among adolescents: Benefits and risks. Adolescent Psycbiatry, 4, 73-80. https://doi.org/10.2174/221067660402140709115810

Reyes, S. \& Ferragut, M. (2016). Fortalezas psicológicas y diferencias de sexo en adolescentes [Character strengths and sex differences in adolescents]. Escritos de Psicología, 9, 28-36. https://doi.org/10.5231/psy.writ.2016.2811

Rice, E., Gibbs, J., Winetrobe, H., Rhoades, H., Plant, A., Montoya, J., \& Kordic, T. (2014). Sexting and sexual behavior among middle school students. Pediatrics 134, 21-28. https://doi.org/10.1542/peds.2013-2991

Ringrose, J., Gill, R., Livingstone, S., \& Harvey, L. (2012). A qualitative study of children, young people and 'sexting': A report prepared for the NSPCC. National Society for the Prevention of Cruelty to Children, London, UK. Available at: https://bit.ly/2NQ1PNj

Ševčíková, A. (2016). Girls and boys experience with teen sexting in early and late adolescence. Journal of Adolescence, 51, 156-162. https://doi.org/10.1016/j.adolescence.2016.06.007

Strassberg, D., Cann, D., \& Velarde, V. (2017). Sexting by high school students. Archives of Sexual Behavior, 46, 1667-1672. https://doi.org/10.1007/s10508-016-0926-9

Strassberg, D. S., McKinnon, R. K., Sustaíta, M. A., \& Rullo, J. (2013). Sexting by high school students: An exploratory and descriptive study. $A r$ chives of Sexual Behavior, 42, 15-21. https://doi.org/10.1007/s10508-0129969-8

Temple, J. R. \& Choi, H. (2014). Longitudinal association between teen sexting and sexual behavior. Pediatrics, 134, 1-6. https://doi.org/10.1542/peds.2014-1974

Temple, J. R., Le, V. D., Van Den Berg, P., Ling, Y., Paul, J. A., \& Temple, B.W. (2014). Brief report: teen sexting and psychosocial health. Journal of Adolescence, 33-36. https://doi.org/10.1016/j.adolescence.2013.10.008

Toner, E., Haslam, N., Robinson, J., \& Williams, P. (2012). Character strengths and wellbeing in adolescence: Structure and correlates of the Values in Action Inventory of Strengths for Children. Personality and Individual Differences, $\quad 52, \quad 637-642$ https://doi.org/10.1016/j.paid.2011.12.014

Van Ouytsel, J., Van Gool, E., Ponnet, K., \& Walrave, M. (2014). Brief report: The association between adolescents' characteristics and engagement in sexting. Journal of Adolescence 37, 1387-1391. https://doi.org/10.1016/j.adolescence.2014.10.004

Van Ouytsel, J. E., Van Gool, E. Walrave, M. Ponnet, K., \& Peeters, E. (2016). Sexting: Adolescents' perceptions of the applications used for, 
motives for, and consequences of sexting. Journal of Youth Studies, 123, 1-25. https://doi.org/10.1080/13676261.2016.1241865

Vázquez, C. \& Hervás, G. (2007). Adaptación española del Cuestionario VIA de Fortalezas para niños [Spanish adaptation of the VIA Inventory of Strengths for Children]. Retrieved from: http://www.authentichappiness.sas.upenn.edu/Defaultaspx.

Wagner, L. (2019). Good character is what we look for in a friend: Character strengths are positively related to peer acceptance and friendship quality in early adolescents. Journal of Early Adolescence, 39, 864 -903. https://doi.org/10.1177/0272431618791286

Weber, M. \& Ruch, W. (2012). The role of a good character in 12-year-old school children: Do character strengths matter in the classroom? Child Indicators Research, 5, 317-334. https://doi.org/10.1007/s12187-011$9128-0$
Ybarra, M. \& Mitchell, K. (2014). "Sexting" and its relation to sexual activity and sexual risk behavior in a national survey of adolescents. Journal of Adolescence Health, 55, 757-764. https://doi.org/10.1016/j.jadohealth.2014.07.012

Yépez-Tito, P., Ferragut, M., \& Blanca, M. J. (2018). Prevalence and profile of sexting among adolescents in Ecuador. Journal of Youth Studies, 22, 501-519. https://doi.org/10.1080/13676261.2018.1515475

Yépez-Tito, P., Ferragut, M., \& Blanca, M. J. (2020). Sexting in adolescence: The use of technology and parental supervisión. Revista Latinoamericana de Psicología, 52, 115-130. https://doi.org/10.14349/rlp.2020.v52.12

Zuckerman, M. (1994). Behavioral expressions and biosocial bases of sensation seeking. New York: Cambridge University Press. 